Pengaruh Kompetensi Anggota DPRD dan Aparatur Pemerintah Daerah, Pelaksanaan Sistem Informasi Akuntansi, Penganggaran Serta Kualitas Informasi Keuangan Terhadap Prinsip-Prinsip Tata Kelola Pemerintah Daerah Yang Baik : Survey Pada Kabupaten/Kota Di Jawa Barat (Nunuy Nur Afiah)

\title{
PENGARUH KOMPETENSI ANGGOTA DPRD DAN APARATUR PEMERINTAH DAERAH, PELAKSANAAN SISTEM INFORMASI AKUNTANSI, PENGANGGARAN SERTA KUALITAS INFORMASI KEUANGAN TERHADAP PRINSIP-PRINSIP TATA KELOLA PEMERINTAH DAERAH YANG BAIK: SURVEY PADA KABUPATEN/KOTA DI JAWA BARAT
}

\author{
Nunuy Nur Afiah \\ Fakultas Ekonomi Jurusan Akuntansi Universitas Padjadjaran \\ JL. Dipati Ukur no. 35 Bandung 40132 \\ nnafiah@yahoo.com
}

\begin{abstract}
ABSTRAK. Penelitian ini bertujuan untuk menguji Pengaruh Kompetensi Anggota DPRD, Kompetensi Aparatur Pemda, Pelaksanaan Sistem Informasi Akuntansi, Penganggaran, dan Kualitas Informasi Akuntansi Terhadap Prinsip-Prinsip Tata Kelola Pemda yang Baik. Metode penelitian yang digunakan adalah descriptive dan explanatory survey terhadap 25 kabupaten/kota di Jawa Barat. Pengumpulan data dilakukan dengan teknik survey menggunakan instrument kuesioner. Dilengkapi dengan teknik observasi. Dilaksanakan sejak bulan September 2003 sampai dengan bulan Agustus 2004. Metode analisis menggunakan Path Analysis. Kesimpulan penelitian ini adalah Kompetensi Anggota DPRD, Kompetensi Aparatur Pemda, Pelaksanaan Sistem Informasi Akuntansi, Penganggaran, dan Kualitas Informasi Akuntansi berpengaruh terhadap Prinsip-Prinsip Tata Kelola Pemda yang Baik.
\end{abstract}

Kata kunci: Keuangan Daerah, Kompetensi, Sistem Informasi Akuntansi, Penganggaran.

THE IMPACT OF THE COMPETENCE OF LOCAL HOUSE OF REFRESENTATIVE MEMBERS, THE COMPETENCE OF LOCAL GOVERNMENT APPARATUS, AND THE APPLICATION OF ACCOUNTING INFORMATION SYSTEM ON BUDGETING: SURVEY ON LOCAL GOVERNMENT IN WEST JAVA

\begin{abstract}
The objective of this research is to investigate The Impact Of The Competence Of Local House Of Representatives Members, The Competence Of Local Government apparatus, The Application of Accounting Information System, Budgeting And Financial Information Quality on The Principles of Good Local Governmental Governance. The methods employed are descriptive and explanatory surveys on 25 cities in West Java. Data collection is conducted using surveying techniques with questionnaire complimented with observation. The research was conducted from September 2003 until August 2004. Analysis method used is Path Analysis. Conclusions drawn are the competence of Local House Of Representatives Members, the competence of Local Government apparatus, the
\end{abstract}


application of accounting information system, budgeting and the quality of financial information partially and simultaneously affect the principles of good local governmental governance.

Keywords: Local financial management, competence, Accounting Information System, Budgeting, Good Government Governance.

\section{PENDAHULUAN}

Era reformasi pemerintahan yang ditandai dengan munculnya konsep otonomi daerah, telah memunculkan tuntutan pelayanan publik dalam rangka memajukan perekonomian daerah. Pencapaian tujuan tersebut memerlukan persyaratan tertentu, dan memerlukan penjabaran operasional lebih lanjut. Persyaratan yang harus ada antara lain terciptanya kehidupan berdemokrasi, tegaknya supremasi hukum, penataan ulang pemerintahan (reinventing government), dan penguatan sumberdaya manusia yang harus dipandang sebagai intellectual asset yang penting. Sedangkan dalam penjabaran operasionalnya dibutuhkan reformasi seperangkat sistem administrasi publik yang terpadu meliputi reformasi anggaran, sistem informasi akuntansi, audit dan reformasi kelembagaan.

Dalam konteks penerapan di Indonesia, terutama pada organisasi pemerintahan, peran aparat dan DPRD dalam pertimbangan penyusunan kebijakan fiskal, dalam proses anggaran, dan sampai pada penyelenggaraan akuntansi di sektor publik sangatlah penting. Peran itu menyangkut kapabilitas analitis yang mencakup pengetahuan, keterampilan, dan pengalaman aparat dan DPRD, terutama di bidang penganggaran dan sistem informasi akuntansi. Ketiadaan latar belakang dibidang akuntansi akan menyebabkan ketidakmampuan dalam melakukan analisa pelaporan keuangan atau ketidakmampuan dalam memahami laporan akuntansi internal, yang digunakan dalam upaya untuk mengelola pemerintahan yang lebih efektif.

United Nation Development Program (UNDP) mendefinisikan governance sebagai the exercise of political, economic, and administrative authority to manage a nation's affair at all levels. Karakteristik good governance berdasarkan UNDP meliputi: participation, rule of law, tranparency, responsiveness, consensus orientation, equity, eficiency \& effectiveness, accountability, strategic vision. Dari 8 karakteristik tersebut setidaknya 3 hal yang dapat diperankan oleh akuntansi sektor publik yaitu penciptaan transparansi, akuntabilitas publik, dan pengukuran efisiensi dan efektivitas. Sedangkan yang dapat diperankan oleh penganggaran dengan pendekatan kinerja adalah pelibatan partisipasi masyarakat, memenuhi aturan hukum, merespon harapan masyarakat, berkeadilan dan menggunakan visi strategis, serta berorientasi pada efisiensi dan efektivitas.

Upaya reformasi yang telah melahirkan UU No 32 tahun 2004 tentang Pemerintahan Daerah dan UU No 33 tahun 2004 tentang Perimbangan Keuangan Pusat dan Daerah, pada pelaksanaannya masih membutuhkan banyak pembenahan, yang bagi penelitian ini merupakan fenomena yang menarik untuk 
diteliti lebih jauh. Salah satu dari masalah yang muncul adalah pertama, masih tetap kuatnya intervensi kebijakan pemerintah pusat dalam menentukan aspekaspek desentralisasi fiskal, ditambah dengan tidak cukupnya atau sebaliknya tumpang tindih informasi yang diterima oleh daerah sehingga menyebabkan tidak efektifnya manajemen keuangan di tingkat pemerintah daerah.

Kedua, sistem anggaran yang berbasis kinerja yang mulai diterapkan di pemerintah provinsi, kabupaten dan kota semenjak diterapkannya UU No 17 tahun 2003 tentag Keuangan Negara, masih memerlukan pembenahan dalam hal proses/mekanisme penganggaran yang berorientasi pada konsep perencanaan strategis, dan value for money mencakup keekonomisan, efisiensi, dan efektivitas dapat mencapai sasarannya.

Ketiga, mengenai sistem informasi akuntansi. Disini ada kegamangan dalam penentuan basis akuntansi yang akan diterapkan apakah basis kas, basis kas menuju akrual, atau basis akrual. Sehingga mempengaruhi proses pencatatan pelaporan serta kejelasan tujuan pelaporan keuangan. Di bidang sistem informasi akuntansi inipun muncul 2 perspektif dalam melihat kasus sistem informasi akuntansi di daerah, yaitu perspektif pemerintah pusat dalam kepentingannya dengan kebijakan fiskal nasional, dan perspektif daerah dalam kaitannya dengan otonomi daerah. Kepentingan pusat yang menonjol dan sifat preskriptifnya ini menyebabkan ketidakjelasan arah sistem akuntansi di daerah dalam mencapai tujuannya.

Keempat, Sistem informasi akuntansi akhirnya akan menghasilkan output berupa pelaporan keuangan yang dalam hal ini pelaporan keuangan daerah yang dapat mencerminkan kinerja keuangan daerah. Masalahnya selama ini, sistem informasi akuntansi yang ada belum memadai untuk dapat dijadikan alat penilaian kinerja pemda. Akibat hal-hal ini: pelaksana belum kompeten, proses pengelolaan belum memadai, teknologi informasi belum berkembang, maka secara umum kualitas informasi keuangan yang dihasilkan oleh pemerintah daerah belum sesuai dengan yang diharapkan masyarakat.

Kelima, menyangkut audit keuangan daerah. Adanya reformasi yang digulirkan ke daerah dengan diterapkannya sistem anggaran kinerja, dan berubahnya sistem pencatatan tunggal (single entry system) ke sistem pencatatan berpasangan (double entry system) menyebabkan berubahnya media pencatatan dan proses pelaporan keuangan di daerah.

Penelitian mengenai masalah pengelolaan keuangan daerah serta kaitanyya terhadap penerapan prinsip Good Governmental Governance disajikan dengan judul:

'Pengaruh Kompetensi Anggota DPRD, Kompetensi Aparatur Pemerintah Daerah, Pelaksanaan Sistem Informasi Akuntansi, Penganggaran, serta Kualitas Informasi Keuangan Terhadap Prinsip-Prinsip Tata Kelola Pemerintahan Yang Baik." 


\section{METODE PENELITIAN}

Penelitian ini tidak hanya menggambarkan fakta-fakta empiris, tetapi juga bertujuan menjelaskan hubungan antar variabel dan menguji hipotesis (Singarimbun, 1995), karena itu penelitian ini termasuk penelitian deskriptif eksplanatori.

Variabel dalam penelitian ini dikelompokkan kedalam 2 variabel yaitu :

1. Variabel Kompetensi anggota DPRD $\left(X_{1}\right)$ dan Kompetensi Aparatur Pemda dinyatakan dengan $\left(X_{2}\right)$, Pelaksanaan Sistem Informasi Akuntansi $\left(X_{3}\right)$, Penganggaran $\left(\mathrm{X}_{4}\right)$ dan Kualitas informasi keuangan $(\mathrm{Y})$ diklasifikasikan sebagai variabel bebas (eksogen).

2. Variabel Prinsip-prinsip Tata kelola Pemerintah Daerah yang baik (the principles of Good Local Government Governance) dinyatakan dengan (Z) diklasifikasikan sebagai Variabel tak bebas (endogen).

Populasi sasaran (target population) dalam penelitian ini adalah seluruh pemerintah kabupaten/kota di Jawa Barat yang berjumlah 25 (N). Semua anggota populasi akan diambil, dengan kata lain dilakukan teknik sensus.

Unit analisis dalam penelitian ini adalah pemerintah kabupaten/kota. Pengumpulan data dilakukan dengan teknik survei menggunakan instrumen kuesioner, yang diisi oleh responden dari setiap kabupaten / kota yaitu dari anggota DPRD dan dari aparatur pemda. Untuk melengkapi data agar komprehensif dan objektif dilengkapi dengan wawancara, dan observasi.

Untuk melihat kuat-lemahnya pengaruh atau tinggi-rendahnya keeratan hubungan antar variabel digunakan klasifikasi Guilford (1956: 145) sebagai berikut:

Less than 0,20 : slight almost weighlegible relationship

$0,20-0,40:$ : low correlation

$0,40-0,70 \quad:$ moderate correlation

$0,70-0,90 \quad:$ high correlation

$0,90-1,00 \quad$ : very high correlation

\section{HASIL PENGUJIAN HIPOTESIS}

Hasil perhitungan koefisien jalur kompetensi anggota DPRD (X1) dan kompetensi aparatur pemerintah daerah (X2), pelaksanaan sistem informasi akuntansi (X3), penganggaran (X4) kualitas informasi keuangan ( $Y$ ) terhadap prinsip-prinsip tata kelola pemerintah daerah yang baik (Z) disajikan pada Diagram Substruktur 1 dibawah ini. 


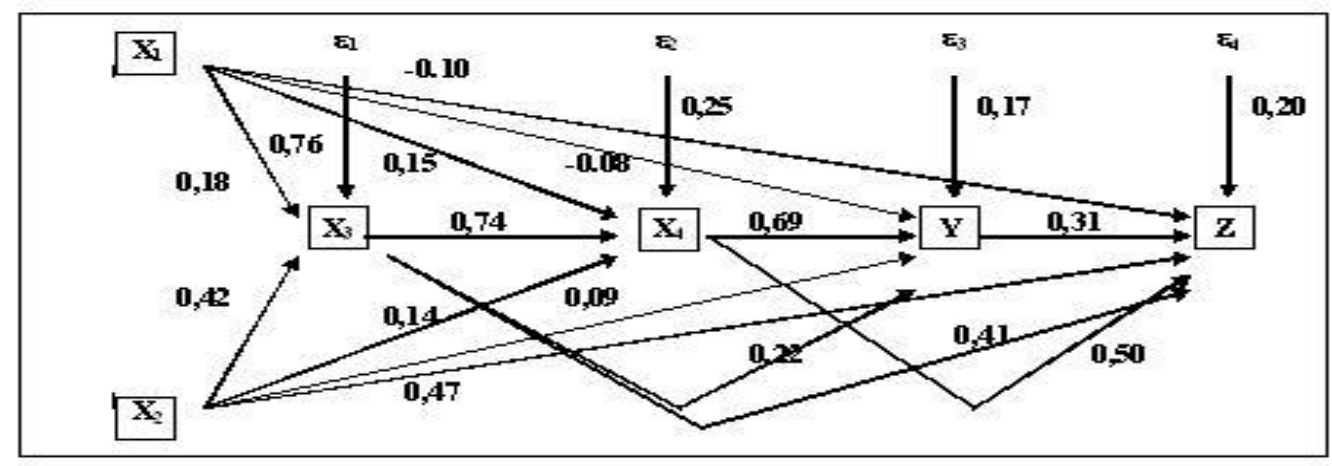

Gambar 1. Substruktur 1

Keterangan:

X1 : Kompetensi Anggota DPRD

X2 : Kompetensi Aparatur Pemerintah Daerah

X3 : pelaksanaan Sistem Informasi Akuntansi

$X 4$ : Penganggaran

$Y$ : Kualitas informasi Keuangan

Z : Prinsip-prinsip Tata Kelola Pemerintah Daerah yang baik

Sesuai dengan kriteria yang telah ditentukan maka keputusan penerimaan atau penolakan hipotesis Ho disajikan pada tabel 1 sebagai berikut.

Tabel 1. Hasil Pengujian Hipotesis Kompetensi Anggota DPRD dan Aparatur Pemerintah Daerah, pelaksanaan sistem informasi akuntansi, penganggaran, kualitas informasi keuangan terhadap PrinsipprinsipTata kelola pemerintah daerah yang baik

\begin{tabular}{|l|l|}
\hline $\begin{array}{l}\text { Pengaruh } \\
\text { Variabel }\end{array}$ & $\begin{array}{l}\text { Koefisien } \\
\text { Jalur }\end{array}$ \\
\hline X1terhadap Z & $-0,10$ \\
\hline X2 terhadap Z & 0,47 \\
\hline X3 terhadap Z & 0,41 \\
\hline X4 terhadap Z & 0,50 \\
\hline Y terhadap Z & 0,32 \\
\hline
\end{tabular}

(a) Dari tabel diatas terlihat koefisien jalur untuk X1 terhadap Z adalah sebesar 0,10 sehingga pengaruh langsungnya sebesar $(-0,10)^{2} \times 100 \%=-0,01 \%$. Dengan demikian kompetensi anggota DPRD (X1) berpengaruh terhadap 
Prinsip-prinsip tata kelola pemerintah daerah yang baik (Z), namun pengaruh tersebut sangat lemah.

(b) Dari tabel diatas terlihat koefisien jalur untuk X2 terhadap $\mathrm{Z}$ adalah sebesar 0,47 sehingga pengaruh langsungnya sebesar $(0,47)^{2} \times 100 \%=22 \%$. Dengan demikian kompetensi aparatur pemerintah daerah (X2) berpengaruh terhadap Prinsip-prinsip tata kelola pemerintah daerah yang baik (Z).

(c) Dari tabel diatas terlihat koefisien jalur untuk pengaruh pelaksanaan sistem informasi akuntansi (X3) terhadap Prinsip-prinsip tata kelola pemerintah daerah yang baik ( $Z$ ) adalah sebesar 0,41 sehingga pengaruh langsungnya sebesar $(0,41)^{2} \times 100 \%=17 \%$. Dengan demikian pelaksanaan sistem informasi akuntansi (X3) berpengaruh terhadap Prinsip-prinsip tata kelola pemerintah daerah yang baik $(Z)$.

(d) Dari tabel diatas terlihat koefisien jalur untuk pengaruh penganggaran (X4) terhadap Prinsip-prinsip tata kelola pemerintah daerah yang baik (Z) adalah sebesar 0,50 sehingga pengaruh langsungnya sebesar $(0,50)^{2} \times 100 \%=25 \%$. Dengan demikian penganggaran (X4) berpengaruh terhadap Prinsip-prinsip tata kelola pemerintah daerah yang baik (Z).

(e) Dari tabel diatas terlihat koefisien jalur untuk pengaruh kualitas informasi keuangan $(Y)$ terhadap Prinsip-prinsip tata kelola pemerintah daerah yang baik (Z) adalah sebesar 0,32 sehingga pengaruh langsungnya sebesar $(0,32)^{2}$ $\times 100 \%=10 \%$. Dengan demikian kualitas informasi keuangan $(\mathrm{Y})$ berpengaruh terhadap Prinsip-prinsip tata kelola pemerintah daerah yang baik (Z).

(f) Pengaruh secara simultan kompetensi anggota DPRD (X1), kompetensi aparatur pemerintah daerah (X2), pelaksanaan sistem informasi akuntansi $(X 3)$, penganggaran $(X 4)$, dan kualitas informasi keuangan $(Y)$ terhadap Prinsip-prinsip tata kelola pemerintah daerah yang baik (Z) adalah sebesar $\mathrm{R}$ $(0,891)^{2} \times 100 \%=80 \%$, yang artinya berdasarkan ketegori Guilford pengaruh tersebut kuat. Masih ada $20 \%$ pengaruh variabel lainnya (epsilon) diluar X1，X2，X3，X4 dan Y yang tidak diteliti, seperti terlihat dalam gambar 1.4 diatas. Adapun perhitungan lengkap pengaruh langsung dan tidak langsungnya seperti dalam tabel 2 dibawah ini. 
Tabel 2. Jumlah Pengaruh Kompetensi anggota DPRD (X1), Kompetensi Aparatur (X2), Pelaksanaan Sistem Informasi Akuntansi (X3), Penganggaran (X4) dan Kualitas Informasi Keuangan $(Y)$ terhadap Prinsip-prinsip tata kelola pemerintah daerah yang baik ( $Z$ ).

Hasil uji jumlah pengaruh langsung X1 $(-0,10)^{2} \times 100 \%=0,01 \%$.

terhadap Z

Hasil uji jumlah pengaruh langsung X2 $(0,47)^{2} \times 100 \%=22 \%$.

terhadap Z

Hasil uji jumlah pengaruh langsung X3 $(0,41)^{2} \times 100 \%=17 \%$.

terhadap Z

Hasil uji jumlah pengaruh langsung $X 4 \quad(0,50)^{2 \times} 100 \%=25 \%$.

terhadap Z

Hasil uji jumlah pengaruh langsung $Y(0,32)^{2} \times 100 \%=10 \%$.

terhadap Z

\begin{tabular}{ll}
\hline Jumlah pengaruh tidak langsung : & $6 \%$ yang terdiri atas: \\
X1-Z-X2 & $2(-0,1)(0.215)(0.47)=-2 \%$ \\
$X 1-Z-X 3$ & $2(-0,1)(0.27)(0.41)=-2 \%$ \\
$X 1-Z-X 4$ & $2(-0,1)(0.376)(0.50)=-3 \%$ \\
$X 1-Z-Y$ & $2((-0,1)(-0.261)(0.31)=2 \%$ \\
$X 2-Z-X 3$ & $2(0.47)(0.46)(0.41)=18 \%$ \\
$X 2-Z-X 4$ & $2(0.47)(0.51)(0.50)=24 \%$ \\
$X 2-Z-Y$ & $2(0.47)(-0.528)(0.31)=-15 \%$ \\
$X 3-Z-X 4$ & $2(0.41)(0.84)(0.50)=34 \%$ \\
$X 3-Z-Y$ & $2(0.41)(-0.82)(0.31)=-21 \%$ \\
$X 4-Z-Y$ & $2(0.50)(-0.89)(0.31)=-28 \%$ \\
& \\
\hline Jumlah pengaruh langsung dan & tidak \\
langsung $X 1, X 2, X 3, X 4, Y$ ke $Z$ & \\
\hline Epsilon $(\varepsilon)$ & $(100 \%-80 \%)=20 \%$ \\
\hline
\end{tabular}

\section{PEMBAHASAN}

Penganggaran mempunyai pengaruh signifikan terhadap prinsip-prinsip tata kelola pemerintah daerah yang baik, hal ini sesuai dengan ide good governance seperti yang dilaporkan oleh UNDP (2003) dan World Bank (2003) dengan menurunkan prinsip-prinsip : participation, rule of law, transparency, responsiveness, consensus orientation, equity, efficiency, effectiveness, accountability, strategic vision. Perubahan paradigma penganggaran diimplementasikan di pemerintah daerah melalui perangkat UU No 17/2003 tentang Keuangan Negara, UU No 32/2004 tentang Pemerintahan Daerah, UU No 33/2004 tentang Perimbangan Keuangan Pusat dan Daerah, serta Permendagri 13 tahun 2006. Perubahan tersebut tidak terlepas dari Reformasi Pengelolaan Keuangan Negara, yang juga mengikuti trend perubahan di dunia yang tengah 
terjadi (Sjahruddin Rasul, 2003). Hal yang baru dari reformasi penganggaran ini adalah penekanan fungsi anggaran sebagai fungsi akuntabilitas, alat manajemen dan alat kebijakan ekonomi (budgeting as a function of accountability, management of on going activities, and tool of economic policy). Selanjutnya juga diperkenalkan asas akuntabilitas berorientasi hasil (result oriented accountability) atau dikenal dengan istilah akuntabilitas kinerja (performance accountability). Implementasinya melalui anggaran berbasis kinerja. Serta diadopsinya prinsip transparansi kepada publik. Dokumen anggaran (APBD) bukanlah dokumen rahasia, namun sebaliknya adalah dokumen yang harus diumumkan kepada publik untuk dicermati dan ditelaah.

Kompetensi aparatur berpengaruh signifikan terhadap prinsip-prinsip tata kelola pemerintah daerah yang baik. Reformasi dalam bidang pemerintahan, mencakup beberapa perubahan dalam beberapa aspek penting antara lain : penataan kelembagaan (institutional arrangment), reformasi aparatur birokrasi (civil servant reform), juga reformasi sistem pengelolaan keuangan negara (the new financial management reform). Khusus mengenai reformasi aparatur birokrasi idenya adalah bahwa aparatur harus bertanggungjawab atas semua aktivitas yang dilakukannya pada stake holders (Richard Mulgan, 1997). Dalam rangka menjalankan semua tanggung jawab itulah diperlukan adanya kompetensi aparatur pemda, agar semua aktivitas yang dipercayakan padanya (mereka) dapat dipertanggung-jawabkan sebaik-baiknya. Karena tanpa kompetensi yang memadai, maka akuntabilitasnya menjadi rendah. Hal ini juga sesuai dengan pendapat Premchand (1983) bahwa kompetensi pengelola amat dibutuhkan dalam pertimbangan penyusunan kebijakan fiskal, untuk menghasilkan sebuah kebijakan fiskal yang koheren. Karena ketidak mampuan aparatur dalam menangani pengelolaan keuangan, serta ketiadaan latar belakang di bidang akuntansi akan menyebabkan ketidak-mampuan aparatur dalam melakukan analisa laporan keuangan atau ketidak-mampuan dalam memahami laporan akuntansi internal, yang digunakan dalam upaya untuk mengelola pemerintahan yang lebih efektif.

Pelaksanaan sistem informasi akuntansi berpengaruh signifikan terhadap prinsip-prinsip tata kelola pemerintah daerah yang baik, hal ini sesuai dengan ide i good governance seperti yang dilaporkan oleh UNDP (2003) dan World Bank (2003) khususnya prinsip transparency, efficiency, effectiveness, dan accountability, dimana dalam 3 aspek tersebut, sistem informasi akuntansi bisa memainkan peranannya. Di Indonesia, untuk tingkat pemerintah daerah basis akuntansi tidak diubah sekaligus yaitu tetap menggunakan basis kas menuju akrual (cash toward accrual basis). Sampai pada paling cepat tahun 2013 diharapkan pemda sudah mampu mengadopsi basis akrual. Sistem informasi akuntansi ini menjadi instrumen penting yang dapat mendukung akuntabilitas publik, melalui pelaporan keuangan yang dihasilkannya.

Maka dalam memenuhi tuntutan yang semakin kompleks untuk menunjang prinsip akuntabilitas, negara-negara maju telah mensyaratkan tidak hanya pertanggung-jawaban keuangan yang harus dipublikasikan kepada masyarakat, 
tetapi juga pertanggung-jawaban non keuangan yang lazim dikenal dengan sebutan Laporan Kinerja (Performance Report atau Accountability Report). Laporan kinerja ini memuat perspektif tidak saja historis seperti yang tersaji dalam laporan keuangan, namun juga informasi sekarang dan yang akan datang. Dengan adanya pertanggung-jawaban keuangan ini (yang dilengkapi dengan pelaporan non keungan) akan dapat dilakukan evaluasi dan penilaian atas instansi pemerintah baik untuk jangka pendek maupun jangka panjang. Perlu langkah yang bertahap untuk sampai bisa memenuhi prinsip akuntabilitas dalam mewujudkan Good Governance di sektor pemerintah, khususnya untuk pemerintah daerah. Perbaikan sistem informasi akuntansi menjadi keharusan karena terbukti signifikan dalam menunjang Good Governance di sektor pemerintah, khususnya untuk pemerintah daerah.

Selanjutnya kualitas informasi keuangan berpengaruh signifikan pada prinsipprinsip tata kelola pemerintah daerah yang baik Sejalan dengan itu, pelaksanaan sistem informasi akuntansi akan mampu meningkatkan kualitas informasi keuangan yang memiliki dimensi dapat dipahami, relevan, dapat diandalkan dan dapat dibandingkan menjadi tolok ukur dari kinerja pemda. Masih sangat lemahnya pengaruh kompetensi anggota DPRD terhadap Prinsip-prinsip Tata Kelola Pemerintah Daerah Yang Baik, harus mendapat perhatian serius, karena seperti yang dikemukakan John Stuart Mill (1861) jauh sebelum abad informasi seperti sekarang ini,dan jauh sebelum diperkenalkannya konsep New Public Management di era 1980-an, dia telah mengangkat masalah hubungan birokrasi dan pemerintahan perwakilan-yang biasanya disebut sebagai demokrasi oleh banyak pihak-dalam sebuah essay " Considerations on Representative Government " yang ditulis tahun 1861, disitu Ia menjelaskan teori pemerintahannya (Amerika). Dengan demikian peran anggota DPRD sebagai representasi rakyat yang seharusnya memainkan peran penting didalam melindungi dan memfasilitasi pemerintahan perwakilan ini harus tampil dengan kompetensi dan komitmen yang diperbaharui untuk mendukung prinsip-prinsip tata kelola pemerintah daerah yang baik (the principles of good government governance).

Dengan pengaruh bersama kompetensi anggota DPRD , kompetensi aparatur pemda, pelaksanaan sistem informasi akuntansi, dan Penganggaran serta kualitas informasi keuangan yang menunjukkan pengaruh kuat terhadap prinsip-prinsip tata kelola pemerintah daerah yang baik, ditunjukkan dengan besaran pengaruh langsung secara simultan sebesar $80 \%$ (dalam kategori Guilford 0,70-0,90 tergolong pengaruh yang kuat), maka hasil penelitian ini dapat mengkontribusikan umpan-balikan bagi pengayaan konsep tata kelola pemerintah daerah yang baik dengan mengetengahkan 4 faktor pendukung terwujudnya prinsip-prinsip tata kelola pemerintah daerah yang baik meliputi : Kompetensi Aparatur Pemerintah daerah, Pelaksanaan Sistem Informasi Akuntansi yang efektif, Penganggaran yang efektif, dan Kualitas Informasi Keuangan yang bernilai.

Sedangkan besaran epsilon sebesar 20\% mengisyaratkan masih ada pengaruh faktor-faktor lain diluar faktor yang diteliti yaitu : Pertama, penelitian ini 
baru memasukkan salah satu pendekatan Mill yang berfokus pada kompetensi. Padahal dalam menegakkan pemerintahan perwakilan, untuk menciptakan demokrasi masih ada pendekatan lain yaitu partisipasi warga negara. Kedua, dalam dimensi sistem informasi akuntansi, setidaknya ada 5 dimensi pendukung pelaksanaan SIA meliputi dimensi sumberdaya terdiri atas orang, peralatan, perlengkapan, dan data; dimensi tugas terdiri atas pengumpulan, pemrosesan, pengendalian dan pendistribusian informasi; dimensi tujuan,; dimensi pemakai informasi; dan dimensi tahapan terdiri atas input, proses dan output. Penelitian ini baru mengambil 3 dimensi yaitu sumberdaya manusia (aparatur), tujuan, dan tugas. Ketiga, dalam penganggaran, penelitian ini baru menyoroti tahapan proses, sedangkan struktur anggaran belum dicakup. Keempat, dari aspek lingkungan dan kultur yang mungkin dapat mempengaruhi terhadap tata kelola pemerintah. Halhal tersebut yang belum diteliti dalam penelitian ini, bisa menjelaskan epsilon yang masih sebesar $20 \%$

\section{PENUTUP}

Berdasarkan pembahasan hasil penelitian maka dapat ditarik simpulan sebagai berikut :

1. Kompetensi anggota DPRD, kompetensi aparatur pemerintah daerah (pemda), pelaksanaan sistem informasi akuntansi, penganggaran dan kualitas informasi keuangan secara parsial dan simultan berpengaruh terhadap prinsipprinsip tata kelola pemerintah daerah yang baik (the principles of good local government governance). Dengan besaran pengaruh bersama yang menunjukkan kategori pengaruh kuat.

2. Peneliti memberikan saran operasional untuk Pemda, yaitu:

a. Pemda agar melaksanakan desentralisasi fungsi akuntansi ke tingkat unit kerja dinas/badan/kantor untuk lebih memberdayakan unit kerja dinas/badan/kantor, serta mencegah overload tugas dalam bidang akuntansi di sekretariat daerah yang menyebabkan rendahnya kualitas informasi keuangan dan terhambatnya saluran informasi di pemda.

b. Prosedur dan dokumen yang terkait dengan model sistem akuntansi keuangan daerah disajikan dalam bentuk bagan alur document (document flowchart).

c. Basis akuntansi menjadi hal yang penting untuk disarankan pada pembuat kebijakan karena membawa dampak yang luas pada pelaksanaan sistem informasi akuntansi di daerah. Penerapan basis akuntansi akrual yang bertahap, dengan cara menyediakan standar akuntansi keuangan sektor publik, yang betul-betul dapat mengakomodasi pengukuran yang efektif dan konsisten, serta disesuaikan dengan kebutuhan pemda dalam era otonomi daerah

d. Perlu penyiapan SDM secara matang dan sistematis oleh pemda. Selanjutnya pendidikan, pelatihan, dan pengembangan yang 
Pengaruh Kompetensi Anggota DPRD dan Aparatur Pemerintah Daerah, Pelaksanaan Sistem Informasi Akuntansi, Penganggaran Serta Kualitas Informasi Keuangan Terhadap Prinsip-Prinsip Tata Kelola Pemerintah Daerah Yang Baik : Survey Pada Kabupaten/Kota Di Jawa Barat (Nunuy Nur Afiah)

berkesinambungan agar terus diupayakan agar aparatur dapat senantiasa menjaga profesionalitas yang disertai etika dan moral profesi.

\section{DAFTAR PUSTAKA}

Cheng, Rita H., John H. Engstrom, Susan C. Kattelus, Fall. 2002. The Journal of Government Financial Management, Educating government financial managers: University collaboration between business and public administration, Alexandria: vol 51, Iss.3;page 10, 5 pages. http://gateway.proquest.com

Guilford J.P., B. Fruchter. 1956. Fundamental Statistic in Psychology and Education, $5^{\text {th }}$ ed, Mc-Graw-Hill, Tokyo.hal 145

Rasyid, H. A. 1994. Teknik Penarikan Sampel dan Penyusunan Skala, Program Pascasarjana Universitas Padjadjaran, Bandung

Jones, R. and M. Pendlebury. 2000. Public Sector Accounting, $5^{\text {th }}$ Ed,London:Pitman Publishing.

Mardiasmo. 2002. Otonomi \& Manajemen Keuangan Daerah, Yogyakarta: Penerbit Andi

2002. Akuntansi Sektor Publik, Penerbit: Andi,Yogyakarta.

Indriantoro, N., B. Supomo. 1999. Metodologi Penelitian Bisnis untuk Akuntansi dan Manajemen, Edisi I, Yogyakarta:BPFE.

Premchan A. 1989. Government Budgeting and Expenditure ControlsTheory and Practice, International Monetary Fund, Washington D.C.

Singarimbun, M., S. Effendi. 1995. Metode Penelitian Survei, LP3ES, Jakarta 